\title{
Peran Pengadilan Agama dalam Mendukung Perkembangan Industri Keuangan Syariah di Indonesia
}

\author{
Fahadil Amin Al Hasan \\ Universitas Indonesia \\ fahadil.amin@ui.ac.id
}

\begin{abstract}
The legal relationship with the economy has a reciprocal and mutually influencing relationship. That is, an economic activity that is not supported by a good legal tool will result in chaos, this is because the economic actors will perform its activities without standard norms that caused the loss of one party in conducting economic activities. If left alone, this will cause the economic climate in the future to be disturbed. Likewise with the sharia economy. If the legal process, in this case the sharia economic dispute resolution carried out well, then the development of sharia economic and financial industry will be better. The Religious Courts as one of the judicial authorities under the Supreme Court of the Republic of Indonesia plays an important role in advancing the sharia financial industry in Indonesia. This is because the Religious Courts are state institutions that have the authority to resolve the dispute of sharia economy. This paper tries to discuss some important aspects related to the settlement of sharia economic dispute in the Religious Courts, as well as some efforts made by the Supreme Court in strengthening the role of Religious Courts in solving the dispute of sharia economy.
\end{abstract}

Key Words: Religious Courts, Sharia Financial Industry, Sharia Economic Dispute

\section{Pendahuluan}

Hubungan antara hukum dan ekonomi sangat erat dan bersifat timbal balik. Hukum menjadi aspek yang sangat penting dalam kontribusi pertumbuhan ekonomi. Hukum mempunyai posisi di dalam upaya menyediakan kondisi yang dapat memacu tumbuhnya pembangunan ekonomi serta untuk menjaga hubungan antar berbagai elemen dan para pelaku ekonomi. (Iyan 2012). Begitupun dalam pengembangan industri ekonomi dan 
keuangan syariah. Seperti pada industri keuangan umum lainnya, dalam industri keuangan syariah semua aspek memerlukan kejelasan, mulai dari jenis produk, aturan main, sampai dengan penyelesaian sengketa. Bahkan di beberapa aspek penyelesaian sengketa erat kaitannya dengan iklim ekonomi dan keuangan suatu negara. Artinya, jika penyelesaian sengketa disuatu negara dapat dilakukan dengan cepat, baik, dan berkualitas, maka iklim usaha, termasuk pertumbuhan investasi dalam negeri akan semakin baik pula.

Sejauh ini secara umum perkembangan ekonomi syariah di Indonesia menunjukan hal yang positif walupun peningkatannya tidak terlalu sigifikan. Baik itu pada Perbankan Syariah, Lembaga Keuangan Mikro Syariah, Asuransi Syariah, Reasuransi Syariah, Reksadana Syariah, Obligasi Syariah, Surat Berharga Berjangka Menengah Syariah, Sekuritas syariah, Pembiayaan Syariah, Pegadaian Syariah, Dana Pensiun Lembaga Keuangan Syariah, dan Bisnis Syariah. Namun di tahun 2018, pengembangan ekonomi syariah diprediksi akan semakin membaik (Pusat Bisnis dan Ekonomi Syariah Universitas Indonesia 2017). Dengan demikian, permasalahan (sengketa) yang terkait dengan ekonomi syariah dimungkinkan akan sering terjadi.

Dalam hal ini, Pengadilan Agama sebagai salah salah satu pelaksana kekuasaan kehakiman di bawah Mahkamah Agung sangat berperan penting dalam memajukan industri keuangan syariah di Indonesia. Kewenangan dalam menangani penyelesaian sengketa ekonomi syariah tersebut secara tegas tertuang dalam Undang Undang Nomor 03 Tahun 2006 jo. Undang-Undang Nomor 50 Tahun 2009 tentang Peradilan Agama, dan berdasarkan putusan Mahkamah Konstitusi Nomor 93/PUU-X/2012 yang mempertegas kewenangan peradilan agama dalam menangani sengketa perbankan syariah secara litigasi. Tulisan sederhana ini mencoba untuk menguraikan beberapa aspek penting yang terkait dengan penyelesaian sengketa ekonomi syariah di Pengadilan Agama, serta beberapa usaha yang dilakukan oleh Mahkamah Agung dalam menguatkan peran Pengadilan Agama dalam menyelesaikan sengketa ekonomi syariah sebagai usaha dalam memajukan industri keuangan syariah di Indonesia.

\section{Perkembangan Industri Keuangan Syariah di Indonesia}

\section{Perbankan Syariah}

Saat ini market share Perbankan Syariah di Indonesia menyentuh 5,2\% dari total aset bank secara nasional. Jumlah nasabah bank syariah per Januari 2018 menyentuh angka 25 juta nasabah, dengan rincian 21.857 .703 merupakan dana pihak ketiga (orang yang berinvestasi/menabung) dan 4.534 .529 merupakan pembiayaan, piutang, dan salam (orang yang mengjukan pembiayaan). Hingga Maret 2018, jumlah industri Bank Umum Syariah (BUS) tercatat sebanyak 13 bank, jumlah Unit Usaha Syariah (UUS) sebanyak 21 bank, dan BPRS sebanyak 167 bank, serta jaringan kantor sebanyak 2.337 unit di seluruh Indonesia.

al-ạ̣kām Vol. 4, Nomor 1, 2019 
Tabel. 1

Statistik Perkembangan Perbankan Syariah

Desember 2014

\begin{tabular}{lllll}
\hline & $\mathbf{2 0 1 5}$ & $\mathbf{2 0 1 6}$ & $\mathbf{2 0 1 7}$ & $\mathbf{2 0 1 8}$ \\
\hline $\begin{array}{l}\text { Bank Umum Syariah } \\
\text { Jumlah Kantor }\end{array}$ & 12 & 13 & 13 & 13 \\
\cline { 2 - 5 } & 1.990 & 1.869 & 1.825 & 1.824 \\
\hline $\begin{array}{l}\text { Unit Usaha Syariah } \\
\text { Jumlah Kantor }\end{array}$ & 22 & 21 & 21 & 21 \\
\cline { 2 - 5 } & 311 & 332 & 344 & 346 \\
\hline $\begin{array}{l}\text { BPRS } \\
\text { Jumlah Kantor }\end{array}$ & 163 & 166 & 167 & 167 \\
\cline { 2 - 5 } & 446 & 453 & 441 & 446
\end{tabular}

Sumber: Laporan Statistik Perbankan Syariah OJK (Diolah)

Berdasarkan laporan statistik Perbankan Syariah OJK Tahun 2018 (Per Maret 2018), total aset (khusus BUS dan UUS) menyentuh angka Rp 414,185 triliun. Jika dibandingkan dengan Malaysia, jelas Indonesia masih kalah bersaing. Malaysia memiliki aset perbankan syariah per Januari 2014 sejumlah RM 430,222.7 juta. Bahkan menurut Ahmad Buchori selaku Direktur Pengaturan Pengembangan Perizinan dan Pengawasan Perbankan Syariah OJK menjelaskan bahwa asset perbankan syariah Malaysia mencapai 10 kali lipat asset perbankan nasional, yaitu sejumlah US\$ 423,2 miliar. (Detik 2015).

Tabel. 2

Perkembangan Aset Perbankan Syariah (dalam Miliar Rp) di Indonesia

\begin{tabular}{lllll}
\hline & 2015 & 2016 & 2017 & 2018 \\
\hline Bank Umum Syariah & 213.423 & 254.184 & 288.027 & 285.397 \\
\hline Unit Usaha Syariah & 82.839 & 102.320 & 136.154 & 128.789 \\
\hline Jumlah Total & 296.262 & 356.504 & 424.181 & 414.185 \\
\hline
\end{tabular}

Sumber: Laporan Statistik Perbankan Syariah OJK (Diolah)

\section{Pasar Modal Syariah}

Perkembangan pasar modal syariah mencapai tonggak sejarah baru semenjak dengan disahkan dan diberlakukannya Undang-Undang Nomor 19 Tahun 2008 tentang Surat Berharga Syariah Negara (SBSN) pada tanggal 7 Mei 2008. Undang-undang ini diperlukan sebagai landasan hukum untuk penerbitan surat berharga syariah negara atau sukuk negara. Pada tanggal 26 Agustus 2008 untuk pertama kalinya Pemerintah Indonesia menerbitkan SBSN seri IFR0001 dan IFR0002. Pada tanggal 30 Juni 2009, Bapepam-LK telah melakukan 
penyempurnaan terhadap Peraturan Bapepam-LK Nomor IX.A.13 tentang Penerbitan Efek Syariah dan II.K.1 tentang Kriteria dan Penerbitan Daftar Efek Syariah (Bapepam 2015).

Dengan peraturan yang cukup memadai, perkembangan pasar modal syariah menunjukkan pertumbuhan yang cukup baik, pangsa pasar Pasar modal syariah per menembus $14,49 \%$ dari total pangsa pasar secara nasional. Saat ini, total aset pasar modal syariah berjumlah 1,048.48 Triliun dari 3.861,09 Triliun rupiah kapitalisasi pasar modal di Indonesia.

Per kuartal I 2017, terdapat 359 saham syariah dari total 562 saham. Sampai dengan Agustus 2017, jumlah Indek Saham Syariah (ISSI maupun JII) masih tertinggal jika dilihat dari kapitalisasi saham jika dibandingkan dengan IHSG. Hal ini disebabkan karena beberapa saham blue chip di Indonesia tidak memenuhi kriteria saham syariah, seperti perusahaan rokok dan bank konvensional.

Secara umum terdapat dua jenis sukuk berdasarkan penerbitnya, yaitu: sukuk korporasi dan sukuk negara. Hingga akhir Desember 2016, sukuk korporasi memiliki market share sebesar 3,99\% dari segi nilai dan sebesar 10,60 dari segi jumlah. Per 20 April 2017, total outstanding sukuk negara adalah $17 \%$ dari total outstanding Surat Berharga Negara. Negara Indonesia merupakan negara penerbit sukuk global terbesar di dunia, dengan porsi 25,675\% sukuk negara di dunia. Per April 2017, terdapat 8 jenis instrument sukuk negara dengan akumulasi penerbitan mencapai Rp. 670,12 triliun (Pusat Bisnis dan Ekonomi Syariah Universitas Indonesia 2017).

Jika mengacu pada data statistik Reksadana Otoritas Jasa Keuangan (OJK) tahun 2018 dari sektor Reksa Dana Syariah, Total Aktiva Bersih (NAB)-nya terus mengalami peningkatan sejalan dengan jumlah reksa dana syariah. Per bulan Maret 2018, NAB reksa dana syariah mencapai Rp. 31,10 Milyar atau mencapai 6,27\% dari total NAB reksa dana secara keseluruhan, sedangkan jumlah reksa dana syariah menjadi 190 atau mencapai $10,28 \%$ dari total reksa dana yang ada.

\section{Industri Keuangan Syariah Non Bank (INKB)}

Lembaga Keuangan Syariah Non Bank atau Industri keuangan Non Bank (IKNB) Syariah yang diawasi oleh Otoritas Jasa keuangan (OJK) meliputi beberapa lembaga, diantaranya: Perusahaan Perasuransian Syariah, Dana Pensiun Syariah, Lembaga Pembiayaan Syariah dan Lembaga Jasa Keuangan Syariah lainnya. Untuk sektor dana pensiun, secara legalitasnya saat ini belum terdapat entitas dana pensiun syariah. Namun demikian, OJK saat ini sedang mempersiapkan konsep pengaturan dan pengembangan dana pensiun syariah.

Secara umum IKNB syariah menunjukkan perkembangan yang positif, hal ini ditunjukkan dari nilai aset IKNB syariah pada posisi 31 Desember 2013 sebesar Rp 41,71

al-ạ̣kām Vol. 4, Nomor 1, 2019 
triliun atau meningkat sebesar $15,86 \%$ dibanding tahun sebelumnya. Sementara itu jumlah pelaku IKNB syariah juga menunjukkan peningkatan jumlah pelaku sebesar $23,75 \%$ dibanding tahun sebelumnya. Jumlah pelaku IKNB Syariah yang tercatat di OJK pada akhir tahun 2013 adalah sebanyak 99 lembaga, berasal dari 49 perusahaan perasuransian syariah, 48 lembaga pembiayaan syariah dan dua lembaga jasa keuangan syariah lainnya.

Lembaga Pembiayaan syariah merupakan entitas yang signifikan porsinya dalam IKNB syariah. Pertumbuhan aset antara lain disebabkan oleh penambahan pelaku usaha serta pengembangan produk dan layanan IKNB Syariah dalam mengakomodasi minat dan kebutuhan masyarakat. Adapun pertumbuhan jumlah pelaku usaha antara lain didasari keyakinan bahwa potensi pasar IKNB syariah masih besar. Nilai aset IKNB syariah pada posisi 31 Desember 2013 menunjukkan sebesar Rp 41,71 triliun. Jika dibandingkan dengan tahun 2012, market share IKNB syariah tahun 2013 mengalami sedikit peningkatan, yaitu sebesar 0,06\%. Peningkatan tersebut diperoleh dari market share aset per akhir tahun 2012 sebesar 3,10\% dan market share aset per akhir tahun 2013 sebesar 3,16\%.(Otoritas Jasa Keuangan 2013).

Dari berberapa perkembangan lembaga keuangan syariah yang sudah dipaparkan di atas, menjelaskan bahwa laju perkembangan LKS di Indonesia menunjukan trend positif. Hal ini merupakan harapan bahwa dikemudian hari Indonesia akan mampu menjadi pusat perkembangan lembaga keuangan syariah di dunia.

\section{Urgensi Kepastian Hukum dan Relasinya dengan Pertumbuhan Industri Keuangan Syariah}

Kepastian hukum adalah salah satu dari tujuan hukum yang pemenuhannya dijamin oleh Undang-Undang Dasar Tahun 1945 pada Pasal 28D. Kepastian hukum sebagai salah satu tujuan hukum tidak akan terlepas dari fungsi hukum itu sendiri. Fungsi hukum yang terpenting adalah tercapainya keteraturan dalam kehidupan manusia dalam masyarakat. Keteraturan ini yang menyebabkan orang dapat hidup dengan berkepastian, artinya orang dapat mengadakan kegiatan-kegiatan yang diperlukan dalam kehidupan bermasyarakat dan dapat pula mengadakan perhitungan atau prediksi tentang apa yang akan terjadi atau apa yang bisa ia harapkan. Dalam dunia usaha, kepastian hukum sangat diperlukan untuk menjamin ketenangan dan kepastian berusaha, termasuk dalam penyelesaian sengketa yang dikemudian hari dapat terjadi. (Kusumaatmadja and Sidharta 2000).

Hubungan hukum (kepastian hukum) dengan ekonomi bukanlah hubungan satu arah, tetapi hubungan timbal balik dan saling mempengaruhi. Kegiatan ekonomi yang tidak didukung oleh hukum akan mengakibatkan terjadi kekacauan, sebab apabila para pelaku ekonomi dalam mengejar keuntungan tidak dilandasi dengan norma hukum maka akan menimbulkan kerugian salah satu pihak dalam melakukan kegiatan ekonomi. Begitupan dengan ekonomi syariah. (Muhtar 2016). Dalam konteks ini yang dimaksud dengan kepastian 
hukum dalam bidang ekonomi adalah adanya konsistensi peraturan dan penegakan hukum di Indonesia, termasuk dalam bahasan ini adalah terkait dengan penyelesaian sengketa ekonomi (Ginting 2008).

\section{Relasi antara Pengadilan Agama dan Industri Keuangan Syariah}

Pengadilan Agama merupakan salah satu unsur utama dalam pengembangan industri keuangan syariah di Indonesia. Hal ini disebabkan karena kepastian hukum dalam berbisnis sangatlah diperlukan bagi semua pelaku bisnis, termasuk bagi pelaku bisnis yang terlibat langsung pada sektor keuangan syariah. Dalam industri keuangan syariah semua aspek memerlukan kejelasan, mulai dari jenis produk, aturan main, sampai dengan penyelesaian sengketa. Dalam kaitannya dengan pertumbuhan ekonomi dan keuangan suatu negara, topik bahasan mengenai penyelesaian sengketa menjadi relevan. Bahkan di beberapa aspek penyelesaian sengketa erat kaitannya dengan iklim ekonomi dan keuangan suatu negara. Artinya, jika penyelesaian sengketa disuatu negara dapat dilakukan dengan cepat, baik, dan berkualitas, maka iklim usaha, termasuk pertumbuhan investasi dalam negeri akan semakin baik pula.

Sebagai salah satu pelaksana kekuasaan kehakiman bagi pencari keadilan yang beragama Islam mengenai perkara perdata tertentu, Pengadilan Agama memiliki peran yang strategis, dalam hal ini ialah terkait dengan penyelesaian sengketa ekonomi syariah (Dewan Perwakilan Rakyat Republik Indonesia 2009). Kewenangan dalam menangani penyelesaian sengketa ekonomi syariah tersebut secara tegas tertuang dalam Undang Undang Nomor 03 Tahun 2006 jo. Undang-Undang Nomor 50 Tahun 2009 tentang Peradilan Agama, dan berdasarkan putusan Mahkamah Konstitusi Nomor 93/PUU-X/2012 yang mempertegas kewenangan peradilan agama dalam menangani sengketa perbankan syariah secara litigasi. Putusan MK ini merupakan penghapusan atas gagasan Choice of Law dan Choice of Forum dalam hal penyelesaian sengketa ekonomi syariah dalam Undang-Undang Nomor 21 Tahun 2008 tentang Perbankan Syariah, yang sebelumnya dalam Penjelasan Pasal 55 ayat (2) menyebutkan bahwa penyelesaian sengketa ekonomi syariah dapat dilakukan melalui musyawarah, mediasi, Peradilan Umum dan Peradilan Agama. Namun dengan putusan ini Mahkamah Konstitusi menegaskan bahwa penyelesaian sengketa ekonomi syariah merupakan kewenangan absolut dari Pengadilan Agama.(Supriyatni, Renny dan Fariana 2017).

Dengan demikian, segala sesuatu yang berkaitan dengan sengketa syariah, terutama dalam perbankan menjadi tugas dan wewenagan Pengadilan Agama dalam menyesaikannya. Oleh karenanya, jika penanganan terhadap sengketa ekonomi syariah dilakukan dengan baik dan profesional, maka secara bersaman akan terjadi pertumbuhan iklim ekonomi ke rah yang lebih baik. Sehingga, cita-cita dan harapan Indonesia menjadi pusat keuangan Islam dunia dapat dengan mudah direalisasikan.

al-aḥkäm vol. 4, Nomor 1, 2019 


\section{Peran Pengadilan Agama dalam Membangun Industri Keuangan Syariah}

\section{Kewenangan Pengadilan Agama dalam Menyelesaikan Sengketa Keuangan Syariah}

Pasal 1 Ayat 3 Undang-Undang Dasar Negara Republik Indonesia 1945 (UUD 1945) menegaskan bahwa Indonesia adalah Negara Hukum. Sejalan dengan ketentuan tersebut, maka salah satu prinsip Negara Hukum adalah adanya jaminan penyelenggaraan kekuasaan kehakiman menegakkan hukum dan keadilan.(Djalil 2010). Dalam pasal 24 Ayat (2) UUD 1945 menjelaskan bahwa Peradilan Agama merupakan salah satu peradilan di lingkungan yang berada di bawah Mahkamah Agung bersama badan peradilan lainnya di lingkungan Peradilan Umum, Peradilan Tata Usaha Negara, dan Peradilan Militer. Dengan semikian, Peradilan Agama adalah satu badan peradilan pelaku kekuasaan kehakiman untuk menyelenggarakan penegakan hukum dan keadilan bagi rakyat pencari keadilan khusus untuk perkara tertentu antara orang yang beragama Islam.

Dalam melaksanakan tugasnya, Pengadilan Agama memilki kewenangan terkait perkara apa saja yang ditanganinya (kompetensi absolut). Dalam perkembangannya, kompetensi Peradilan Agama telah mengalami perubahan. Diantara yang menjadi kewenangannya adalah bidang perkawinan, waris, wasiat, hibah, wakaf, zakat, infaq, shadaqah, dan ekonomi syariah. Terkait dengan kewenagannya dalam penyelesaian sengketa ekonomi syariah dapat dilihat dari perkembangan perubahan kewenangan tersebut pada tabel berikut:

Tabel 3

Kewenangan Peradilan Agama dalam Penyelesaian Sengketa Ekonomi Syariah

\begin{tabular}{|c|c|c|}
\hline No & Undang Undang Peradilan Agama & Keterangan \\
\hline 1 & $\begin{array}{l}\text { Undang Undang No } 7 \text { Tahun } 1989 \\
\text { Tentang Peradilan Agama }\end{array}$ & $\begin{array}{l}\text { Sengketa ekonomi syariah belum menjadi } \\
\text { kewenangan Peradilan Agama }\end{array}$ \\
\hline 2 & $\begin{array}{l}\text { Undang Undang No. } 3 \text { Tahun } 2006 \\
\text { Tentang Peradilan Agama }\end{array}$ & $\begin{array}{l}\text { Pada Pasal } 49 \text { memperluas kewenangan } \\
\text { Peradilan Agama untuk juga menyelesaikan } \\
\text { sengketa dalam bidang ekonomi Syariah }\end{array}$ \\
\hline 3 & $\begin{array}{l}\text { Undang Undang No. } 50 \text { Tahun } \\
2009 \text { Tentang Perubahan Kedua } \\
\text { atas Undang Undang Nomor } 7 \\
\text { Tahun } 1989 \text { Tentang Peradilan } \\
\text { Agama }\end{array}$ & $\begin{array}{l}\text { Memperkuat perluasan kewenangan Peradilan } \\
\text { Agama untuk menyelesaikan sengketa } \\
\text { ekonomi syariah }\end{array}$ \\
\hline
\end{tabular}

Sumber: Yeni Suprianti, 2017

Adapun "ekonomi syariah" yang dimaksudkan dalam undang-undang tersebut adalah segala sesuatu perbuatan atau kegiatan usaha yang dilaksanakan menurut prinsip syariah 
yang meliputi:

a. Perbankan Syariah;

b. Lembaga Keuangan Mikro Syariah;

c. Asuransi Syariah;

d. Reasuransi Syariah;

e. Reksadana Syariah;

f. Obligasi Syariah;

g. Surat Berharga Berjangka Menengah Syariah;

h. Sekuritas syariah;

i. Pembiayaan Syariah;

j. Pegadaian Syariah;

k. Dana Pensiun Lembaga Keuangan Syariah, dan

I. Bisnis Syariah.(Nurhayati 2016)

Dalam kaitannya dengan bisnis syariah, maka macam dan jenisnya sangatlah beragam. Hal ini terkait dengan makna dari bisnis syariah itu sendiri. Adapun maksud dari bisnis syariah adalah segala sesuatu yang berkaitan dengan aktivitas jual beli atau transaksi dalam berbagai bentuknya yang sesuai dengan ketentuan-ketentuan syariah.(Asmuni 2013). Dengan demikian, maka setiap transaksi atau bisnis yang menggunakan akad syariah dapat dikategorikan sebagai bisnis syariah dan dapat diselesaikan di Pengadilan Agama, seperti sengketa yang terjadi pada bisnis Mullti Level Marketing Syariah, Parawisata Halal yang meliputi jasa layanan perhotelan syariah, biro perjalanan syariah, dan SPA syariah yang berdasarkan Fatwa DSN-MUI Nomor 108 segala sesuatu yang berhubungan dengan pelaksanaan parawisata halal harus menggunakan akad berdasarkan syariat Islam, ataupun bisnis-bisnis lainnya.

\section{Penguatan Peran Pengadilan Agama dalam Penyelesaian Sengketa Ekonomi Syariah}

Sebagaimana dijelaskan sebelumnya bahwa penyelesaian sengketa ekonomi syariah menjadi kewenangan Pengadilan Agama. Dengan demikian, penguatan intitusi Pengadilan Agama dalam menyelesaikan perkara ekonomi syariah perlu dilakukan. Dalam hal ini, para hakim di Pengadilan Agama sebagai pejabat yang melakukan kekuasaan kehakiman yang diatur dalam Undang-undang dituntut untuk dapat memahami perekonomian syariah dalam bingkai regulasi Indonesia dan aktualisasi figh Islam, mempunyai wawasan terhadap produk layanan dan mekanisme operasional dari perbankan syariah, lembaga keuangan mikro syariah, reksadana syariah, obligasi dan surat berharga berjangka menengah syariah, sekuritas syariah, pembiayaan syariah, pegadaian syariah, dana pensiun syariah, serta bisnis-bisnis yang berbasis pada akad syariah. Selain itu, para hakim Pengadilan Agama juga perlu meningkatkan wawasan hukum tentang prediksi terjadinya sengketa dalam aktivitas dan kegiatan ekonomi syariah.(Nurhayati 2016).

al-aḥ̂ām vol. 4, Nomor 1, 2019 
Untuk mendukung penyelesaian sengketa ekonomi syariah di Pengadilan Agama, Mahkamah Agung Republik Indonesia setidaknya telah mengeluarkan Peraturan Mahkamah Agung (Perma) yang terkait dengan penyelesaian sengketa ekonomi syariah. Diantara Perma tersebut ialah Perma terkait hukum materiil ekonomi dan keuangan syariah (Perma Nomor 2 Tahun Tahun 2008 tentang Pemberlakuan Kompilasi Hukum Ekonomi Syariah), Perma terkait dengan keharusan hakim yang menangani ekonomi syariah memiliki sertifikat hakim ekomoni syariah (Perma Nomor 5 Tahun 2016 tentang Sertifikasi Hakim Ekonomi Syariah), dan Perma yang terkait dengan hukum acara penyelesaian sengketa ekonomi syariah (Perma Nomor 14 Tahun 2016 tentang Tata Cara Penyelesaian Sengketa Ekonomi Syariah).

a. Lahirnya Perma Nomor 2 Tahun 2008 tentang Pemberlakuan Kompilasi Hukum Ekonomi Syariah (KHES)

Perma Nomor 2 tahun 2008 tentang Kompilasi Hukum Ekonomi Syariah (KHES) merupakan implementasi dari Pasal 49 Undang-Undang Nomor 3 tahun 2006 tentang Peradilan Agama yang memberikan peluang bagi Pengadilan Agama untuk menyelesaiakan sengketa ekonomi syariah yang setelehnya diperkuat oleh putusan Mahkamah Konstitusi Nomor 93/PUU-X/2012. Perma ini menjelaskan bahwa KHES merupakan pedoman yang dapat digunakan oleh hakim dalam menyelesaikan sengketa ekonomi syariah di Pengadilan Agama. Namun demikian, adanya pedoman ini tidak mengurangi tanggung jawab hakim untuk senantiasa menggali dan menemukan hukum untuk menjamin putusan yang dikeluarkannya adil dan benar.

Sebagaimana telah menjadi bahasan para praktisi hukum ekonomi syariah dan para akademisi bahwa masih terdapat beberapa pasal pada KHES yang tidak sesuai dengan praktek ekonomi syariah di lapangan. Khusus dalam pemebahasan ini, penulis telah menulis bahasan khusus mengenai harmonisasi hukum dalam penyelesaian sengketa ekonomi syariah. Dengan demikian, hakim pun harus mengetahui aturanaturan yang berlaku dalam pelaksanaan ekonomi syariah lainnya, seperti UndangUndang Nomor 21 Tahun 2008 tentang Perbankan Syariah, Undang-Undang Nomor 19 Tahun 2008 tentang Surat Berharga Syariah Negara, Undang-Undang Nomor 41 Tahun 2004 tentang Wakaf, Undang-Undang Nomor 23 Tahun 2011 tentang Zakat, dan juga ketentuan lain yang diberikan kewenangan oleh undang-undang seperti Fatwa Dewan Syariah Nasional-Majelis Ulama Indonesia dan Peraturan Otoritas Jasa Keuangan.

b. Lahirnya Perma Nomor 5 Tahun 2016 tentang Sertifikasi Hakim Ekonomi Syariah

Pasca putusan Mahkamah Konstitusi Nomor 93/PUU-X/2012 Pengadilan Agama merupakan satu-satunya lembaga yang berwenang dalam menyelesaikan sengketa ekonomi syariah. Konsekuensi logis dari pelimpahan kewengan tersebut ialah harus siapnya Pengadilan Agama dalam menyelesaikan sengketa ekonomi syariah. Bentuk kesiapan tersebut ialah dengan mempersiapkan para hakim di Pengadilan Agama 
yang mumpuni dalam mengatasi setiap perkara yang masuk untuk segera diselesaikan dengan putusan yang adil dan profesional.

Dalam hal ini Mahkamah Agung sebagai lembaga yang menaungi lembaga peradilan di Indonesia, termasuk Pengadilan Agama, menjawab tantangan tersebut melalui sertifikasi hakim ekonomi syariah. Sehingga setiap perkara ekonomi syariah harus diadili oleh hakim ekonomi syariah yang bersertifikat yang langsung diangkat oleh Ketua Mahkamah Agung Republik Indonesia. Tujuan diselenggarakannya sertifikasi ekonomi syariah ialah untuk meningkatkan efektifitas penanganan perkaraperkara ekonomi syariah di Pengadilan Agama/Mahkamah Syar'iyah sebagai bagian dari upaya penegakkan hukum ekonomi syariah yang memenuhi rasa keadilan. Selain itu, tujuan sertifikasi hakim ekonomi syariah ialah untuk menjawab pihak-pihak baik dikalangan industri maupun praktisi yang meragukan kemampuan Peradilan Agama dalam menyelesaikan sengketa ekonomi syariah.

Dalam prosesnya, para hakim yang memenuhi persyaratan dan dinyatakan lulus oleh Tim Seleksi, akan mengikuti pelatihan yang disiapkan oleh Tim Khusus dan Pusdiklat Teknis Mahkamah Agung Republik Indonesia. Tim pengajarnya terdiri dari berbagai lembaga seperti para praktisi dari Otoritas Jasa Keuangan, Bank Indonesia, Dewan Syariah Nasional, dan praktisi berkompeten lainnya.

Dengan adanya Perma Sertifikasi Hakim Ekonomi Syariah ini diharapkan penyelesaian sengketa ekonomi syariah dapat diselesaikan oleh para hakim yang qualified dan teruji kemampuannya sehingga keraguan di kalangan pelaku industri ekonomi dan keuangan syariah menjadi sirna, berubah menjadi suatu kepercayaan (trust) (Rasyid 2016).

c. Lahirnya Perma Nomor 14 Tahun 2016 tentang Tata Cara Penyelesaian Sengketa Ekonomi Syariah

Setelah menunggu penentian yang cukup lama, akhirya Perma Nomor 14 tahun 2016 tentang Tata Cara Penyelesaian Sengketa Ekonomi Syariah resmi dikeluarkan oleh Mahkamah Agung Republik Indonesia pada tanggal 22 Desember 2016. Perma ini mengatur hukum acara sengketa ekonomi syariah melengkapi Perma Nomor 2 tahun 2008 tentang Kompilasi Hukum Ekonomi Syariah (KHES) sebagai implementasi Pasal 49 Undang-Undang Nomor 3 tahun 2006 tentang Peradilan Agama.

Dalam Perma ini dijelaskan bahwa gugatan terhadap ekonomi syariah dapat dilakukan dengan gugatan sederhana dan gugatan biasa. Gugatan sederha dapat dilakukan jika nilainya di bawah atau senilai 200 juta rupiah yang pada Perma Nomor 2 tahun 2015 tentang Tata Cara Penyelesaian Gugatan Sederhana yang tidak memasukkan sengketa ekonomi sebagai bagian dari objek small claim court. 
Perma ini juga mempertegas bahwa keberadaan arbitrase syariah serta kewenangan pengadilan agama dalam menangani perkara ekonomi syariah dalam hal melaksanakan putusan arbitrase syariah dan pembatalannya. Termasuk pula kewenangan pengadilan agama untuk mengeksekusi hak tanggungan dan fidusia yang menggunakan akad syariah.

Selain itu, Perma menjalaskan atas pengakuan layanan teknologi informasi dalam proses perkara mulai dari pendaftaran gugatan (Pasal 4 dan 7), pemanggilan para pihak (Pasal 8), dan pemeriksaan ahli dalam tahap pembuktian (Pasal 11). Perma ini sejalan dengan Perma Nomor 3 Tahun 2018 yang baru dikeluarkan yang menjelaskan aturan mengenai Administrasi Perkara di Pengadilan secara Elekronik.

Lebih jauh lagi, Perma ini mengatur bahwa penyelesaian sengketa ekonomi syariah harus dilakukan oleh hakim yang telah mendapatkan sertifikat hakim ekonomi syariah sebagaimana dijelaskan pada Perma Nomor 5 Tahun 2016 atau setiaknya jika tidak terdapat hakim yang bersertifikat, maka harus oleh hakim yang telah mengikuti diklat teknis ekonomi syariah.

Dan tidak kalah pentingnya, Perma ini mengatur mengenai pentingnya proses mediasi. Pada pasal 10 dijelaskan bahwa Hakim wajib dengan sungguh-sungguh mengupayakan perdamaian yang tentunya berpedoman pada Perma Nomor 1 Tahun 2016 tentang prosedur Mediasi.

Dalam pelaksanaan Mediasi, terdapat beberapa masukan dari kalangan akademisi bahwa sudah selayogyanya di Pengadilan Agama dibentuk satu unit tersendiri yang khusus menyediakan mediator-mediator (dalam hal ini mediator atas sengketa ekonomi syariah) yang telah bersertifikat atau setidaknya Pengadilan Agama memiliki list mediator-mediator bersertifikat yang berkompeten dalam masalah ekonomi syariah. Penyediaan tenaga-tenaga mediator non hakim sangat dimungkinkan. Salah satu alternatif yang dapat dilakukan adalah dengan kerjasamanya Otoritas Jasa Keuangan (OJK), Dewan Syariah Nasioanal, atau Pusat Mediasi Nasional (PMN) yang pada saat ini elah terakreditasi oleh Mahkamah Agung melalui Surat Keputusan Ketua Mahkamah Agung RI Nomor 136/KMA/SK/VIII/2014 bertanggal 21 Agustus 2014 (Iyan 2012).

\section{Kesimpulan}

Pengadilan Agama merupakan unsur utama dalam pengembangan industri keuangan syariah di Indonesia. Hal ini karena Pengadilan Agama dapat menjamin kepastian hukum dalam berbisnis bagi semua pelaku bisnis, dalam hal ini ialah terkait dengan penyelesaian sengketa ekonomi syariah. Sama halnya dengan ekonomi secara umum, dalam industri keuangan syariah semua aspek memerlukan kejelasan, mulai dari jenis produk, aturan main, sampai dengan penyelesaian sengketa. 
Untuk mendukung Pengadilan Agama dalam menyelesaikan sengketa ekonomi syariah, Mahkamah Agung sebagai lembaga yang membawahi Pengadilan Agama setidaknya telah mengeluarkan beberapa Peraturan Mahkamah Agung (Perma) yang terkait dengan penyelesaian sengketa ekonomi syariah. Diantara Perma tersebut ialah Perma terkait hukum materiil ekonomi dan keuangan syariah (Perma Nomor 2 Tahun Tahun 2008 tentang Pemberlakuan Kompilasi Hukum Ekonomi Syariah), Perma terkait dengan keharusan hakim yang menangani ekonomi syariah memiliki sertifikat hakim ekomoni syariah (Perma Nomor 5 Tahun 2016 tentang Sertifikasi Hakim Ekonomi Syariah), dan Perma yang terkait dengan hukum acara penyelesaian sengketa ekonomi syariah (Perma Nomor 14 Tahun 2016 tentang Tata Cara Penyelesaian Sengketa Ekonomi Syariah).

\section{Daftar Pustaka}

Asmuni. 2013. Bisnis Syariah: Suatu Alternatif Pengembangan Bisnis Yang Humanistik Dan Berkeadilan. Medan: Perdana Publishing.

Bapepam. 2015. "Sejarah Pasar Modal Syariah." Badan Pengawas Pasar Modal Dan Lembaga Keuangan. 2015. http://www.bapepam.go.id/syariah/sejarah_pasar_modal_ syariah.html.

Detik. 2015. "Aset Keuangan Syariah Malaysia Terbesar Di Dunia 10 Kali Lipat Dari RI." Detik Com. 2015. https://finance.detik.com/moneter/d-2941564/aset-keuangan-syariahmalaysia-terbesar-di-dunia-10-kali-lipat-dari-ri.

Dewan Perwakilan Rakyat Republik Indonesia. 2009. Kekuasaan Kehakiman. Jakarta, Indonesia.

Djalil. 2010. Peradilan Agama Di Indonesia. Jakarta: Kencana.

Ginting, Budiman. 2008. "Kepastian Hukum Dan Implikasinya Terhadap Pertumbuhan Investasi Di Indonesia (Pidato Pengukuhan Jabatan Guru Besar Tetap Universitas Sumatera Utara)." Medan.

Iyan, R.Y. 2012. "Peran Hukum Dalam Pembangunan Ekonomi." Journal of Finance 5 (2): 1-15.

Kusumaatmadja, Mochtar, and Arief B. Sidharta. 2000. Pengantar Ilmu Hukum: Suatu Pengenalan Pertama Ruang Lingkup Berlakunya Ilmu Hukum. 1st ed. Bandung: Alumni.

Muhtar, Ahmad. 2016. "Kontribusi Hukum Terhadap Perkembangan Perekonomian Nasional Indonesia." Iqtishodia: Jurnal Ekonomi Syariah 2 (1).

Nurhayati, Siti. 2016. "Penguatan Peran Hakim Pengadilan Agama Dalam Penyelesaian Sengketa Perbankan Syariah Pasca Putusan Mahkamah Konstitusi Nomor 93/ Puu-x/2012." Yudisia 7 (2).

Otoritas Jasa Keuangan. 2013. "Laporan Perkembangan Keuangan Syariah 2013." Otoritas Jasa Keuangan. 2013. www.ojk.go.id/id/data-dan-statistik-/ojk/.../ 
LPKS2013_1410943461.pdf.

Pusat Bisnis dan Ekonomi Syariah Universitas Indonesia. 2017. Indonesia Sharia Economic Outlook 2018-Ekonomi Dan Keuangan Syariah Sebagai Arus Baru Perekonomian Indonesia. Jakarta: PEB FEB UI.

Rasyid, Abdul. 2016. "Sertifikasi Hakim Ekonomi Syariah." 2016.

Supriyatni, Renny dan Fariana, Andi. 2017. "Model Penyelesaian Sengketa Ekonomi Syariah Yang Efektif Dikaitkan Dengan Kompetensi Di Peradilan Agama Dalam Rangka Pertumbuhan Ekonomi Nasional." Jurnal Jurisprudence 7 (1). 